\title{
ORIENTASI KEWIRAUSAHAAN DAN KEMAMPUAN PENJUALAN
}

\author{
GRESTA DELI NURHALIZAH \\ MINTARTI ARIANI \\ FAKULTAS BISNIS DAN EKONOMIKA, UNIVERSITAS SURABAYA
}

Orientasi Kewirausahaan (EO) ialah sebuah pengambilan putusan dalam sebuah organisasi yang mana keputusan tersebut dianggap sebagai keputusan terbaik untuk jalannya kegiatan kewirausahaan. (Bolton \& Lane, 2012). Orientasi Kewirausahaan (EO) juga dapat dijadikan sebagai kelengkapan utama pada karyawan yang ideal untuk memulai pekerjaan. Hal yang dipakai untuk mengukur tingkat Orientasi Kewirausahaan seseorang ialah luas variabel yang di mulai dari kreativitas, selfefficacy, dan self-esteem. (Kattenbach \& Fietze, 2018; Pratono, 2018)

Orientasi kewirausahaan (EO) dapat mencerminkan suatu perusahaan yang memiliki komitmen dan kemampuan. Penilaian Orientasi Kewirausahaan juga dapat didasarkan pada lima elemen yaitu inovasi, proaktif, pengambilan resiko, otonomi dan agresif. (Ngoma, Ernest, Nangoli, \& Christopher, 2017). Tiga dari lima elemen ini telah digunakan pada sebagian besar penelitian orientasi kewirausahaan. Tiga elemen yang digunakan adalah inovasi, proaktif dan pengambilan resiko. ( Bolton \& Lane, 2012). Pengukuran tentang perilaku terutama kemauan untuk mengambil resiko dapat mengindikasikan seberapa mungkin seseorang sukses sebagai pengusaha. (Pratono, 2018)

Dengan memeriksa proaktif dan dimensi pengambilan resiko orientasi kewirausahaan, investor dapat menentukan kemungkinan usaha start up. karena dapat memberikan lebih besar mendapatkan keuntungan pada usaha yang baru saja di rintis. (Kropp, Lindsay, \& Shoham, 2008). Proaktif mengacu pada kesempatan kedepan perspektif yang memperkenalkan produk baru. Inovasi mengacu pada kesediaan mendukung kreativitas dan eksperimentasi produk baru. (Kropp, Lindsay, \& Shoham, 2008). Orientasi kewirausahaan mengarah pada kegiatan praktik, serta putusan yang mengacu pada penambahan inovasi, proaktif dan pengambilan resiko sekaligus bertindak secara otonom dan menjadi agresif. (Kantur, 2016)

\section{KINERJA PERUSAHAAN}

Kinerja perusahaan (FP) adalah kegiatan yang selalu di pergunakan untuk memberikan penilaian terhadap perusahaan yang dilihat dari segi informasi keuangan pada sebuah laporan keuangan. Selain dari sisi sektor financial kinerja keuangan juga dapat dilihat dari sisi non keuangan contohnya seperti reputasi perusahaan (Lee \& Roh, 2012) dan dampak social (Pratono et al, 2017). Reputasi 
perusahaan merupakan salah satu dimensi penting dari kinerja perusahaan. Pemangku kepentingan dalam suatu perusahaan tidak hanya peduli dengan keuangan yang di dapat tetapi juga dengan reputasi perusahaan yang meningkatkan kualitas aset saham tidak berwujud untuk perbandingan kinerja unggul yang berkelanjutan. (Lee \& Roh, 2012; Pratono \& Tjahjono)

Pada dasarnya kinerja perusahaan memiliki hubungan erat dengan kinerja keuangan. Hubungan antara kinerja perusahaan dan kinerja keuangan dapat di nilai dari sisi harga per saham, dan pengembalian aset atau pengembalian dana. (Amini \& Bianco, 2017). Ada lima dimensi kinerja perusahaan, diantaranya adalah omset, produktivitas tenaga kerja, inovasi, diferensiasi produk dan alih teknologi. Variable omset dapat dilihat dari pendapatan perusahaan. (Amini \& Bianco, 2017). Kinerja perusahaan tidak selalu bernilai positif, dalam kinerja perusahaan juga terdapat dampak negatif antara dualitas dan kinerja perusahaan itu sendiri. (Bhatt \& Bhatt, 2017)

Kinerja perusahaan memiliki hubungan erat dengan daya saing produk. Perusahaan yang pada daya saing produk memiliki kinerja yang lebih tinggi daripada perusahaan yang beroperasi di pasar dengan produk yang mempunyai daya saing yang lebih rendah. (Liu, Qu, \& Haman, 2018). Selain ini Kinerja perusahaan juga dapat di ukur dalam basis akuntansi, yang mana di dalamnya terdapat ROA yang memiliki peranan penting. Pada sisi lain korelasi positif antara keringanan non-eksekutif dan kinerja perusahaan di perkuat dengan fase tenaga kerja yang mengarah dalam kontribusi sosial lebih tinggi. (Feng, Wangn, \& Sain, 2015)

Kinerja perusahaan dapat bekerja sama dengan jaringan kolaboratif pada mitra yang berbeda secara subtansial dapat meningkatkan inovasi dengan meningkatkan jumlah dan berbagai pengetahuan. (Oltra, Flor, \& Alfaro, 2018). Dimensi struktural modal sosial internal dapat meningkatkan kinerja perusahaan, contohnya ialah interaksi keluarga terhadap keberhasilan bisnis keluarga. (Mani \& Lakhal, 2015; Pratono et al, 2018). Ada tiga sudut pandang yang digunakan untuk menjelaskan efek resultan dari investasi pada kinerja perusahaan yang berkaitan dengan IT. Pada sudut pandang yang berbeda mungkin disebabkan oleh varians dalam periode sampel, tingkat analisis dan metodologi. (Bose \& Luo, 2014)

Orientasi kewirausahaan (EO) dapat mempengaruhi kinerja perusahaan, disisi lain orientasi kewirausahaan (EO) juga dapat menjadi tolak ukur kesuksesan suatu perusahaan karena dapat dilihat dari hasil pekerjaan para karyawannya. (Bolton \& Lane, 2012). Hubungan antara orientasi kewirausahaan (EO) dengan kinerja perusahaan bergantung pada keterampilan politik dari manajer dalam membimbing usaha. Hal ini juga harus berkaitan dengan keadilan dalam berorganisasi agar membentuk stakeholder dalam menjalankan usaha (Cong, Dempsey, \& Xie, 2017).

Orientasi kewirausahaan memiliki fungsi untuk mengatasi ancaman kompetitif dan untuk menghindari tekanan yang ada dalam kinerja perusahaan. Selain itu EO juga dapat membuat perspektif yang melibatkan pengenalan produk baru dalam membuat perubahan yang lebih baik untuk perusahaan. (Caseiro \& Coelho, 2018). Mempelajari orientasi kewirausahaan memiliki manfaat untuk kinerja perusahaan yaitu berupa menghindari hal yang dapat menyesatkan deskriptif dan normatif. Di lain sisi EO memiliki dua bagian yang tidak boleh disatukan karna dapat membuat efek negatif (Rezaei \& Ortt, 2018) 


\section{KEMAMPUAN PENJUALAN}

Hubungan EO-FP di pengaruhi oleh variable selling capability. Selling capability merupakan kemampuan seseorang ( tenaga penjual) dalam melakukan pendekatan kepada konsumen untuk memperoleh suatu hasil penjualan. (Altintas, et al, 2017) Selling capability tidak selalu berbicara tentang cara menjual barang namun juga berbicara tentang cara membangun dan menjaga kepercayaan selain kepercayaan konsumen selling capability juga berbicara tentang jaringan sosial dengan konsumen (Pratono, 2018)

Hubungan EO-FP dipengaruhi oleh variable selling capability dapat dilihat dari banyaknya konsumen yang loyal kepada perusahaan tersebut. (Gammoh, Mallin, Pullins, \& Johnson, 2018) Firm performance membutuhkan selling capability untuk mendorong perusahaan memberikan lebih banyak waktu untuk mempromosikan bahwa perusahaan dapat di percaya. (Pratono, 2018). Ketika suatu perusahaan membangun hubungan dengan konsumen, keterampilan tenaga kerja penjualan dalam mempromosikan sangat penting untuk membentuk kepuasan dan loyalitas konsumen. (Comer, 2012; Pratono, 2016)

Tenaga kerja penjualan harus memiliki selling capability yang baik dengan didukung oleh rasa percaya diri yang tinggi. (Gammoh, Mallin, Pullins, \& Johnson, 2018). Selain harus menarik konsumen yang loyal, tenaga kerja penjualan juga harus mampu menarik konsumen dengan stratifikasi kehidupan menengah ke atas. (GentileLüdecke, 2014; Pratono \& Mahmood, 2015). Tenaga kerja penjualan juga harus mampu menjalin hubungan dengan perusahaan mancanegara. (Gentile-Lüdecke, 2014)

\section{Bibliography}

Altintas, F., Kurtulmuşoğlu, F. B., Altintas, M. H., Kaufmann, H.R., \& Alkibay, S. (2017). The mediating effects of adaptive selling and commitment on the relationship between management control and sales performance. Euromed Journal of Business, 12(2).

Amini, C., \& Bianco, S. D. (2017). Corporate Social Responsibility and The Performance of Latin American Companies. Corporate Governance: The International Journal of Business in Society, 17(3), 403-445.

Bhatt, P. R., \& Bhatt, R. R. (2017). Corporate Governance and Company Performance in Malaysia. Corporate Governance: The International Journal of Business in Society, 17(5), 896-912.

Bolton, D. L., \& Lane, M. D. (2012). Individual Entrepreneurial Orientation: Development of a measurement instrument. Education + Training, 54(2/3), 219-233. 
Bose, R., \& Luo, X. (. (2014). Investigating The Impact of Security Investments on Company Performance. International Journal of Accounting \& Information Management, 22(3), 194-208.

Caseiro, N., \& Coelho, A. (2018). Business Intelligence and Competitiveness: The Mediating Role of Entrepreneurial Orientation. Competitiveness Review: An International Business Journal, 28(2), 213-226.

Comer, T. D. (2012). Salesperson's listening ability as an antecedent to relationship selling. Journal of Business \& Industrial Marketing, 28(1), 50 - 59.

Cong, C., Dempsey, M., \& Xie, H. M. (2017). Political Skill, Entrepreneurial Orientation and Organizational Justice: A Study of Entrepreneurial Enterprise in China. International Journal of Entrepreneurial Behavior \& Research, 23(1), 20-34.

Feng, M., Wangn, X. A., \& Sain, J. s. (2015). Monetary Compensation, Workforce Oriented Corporate Social Responsibility, and Company Performance. American Journal of Business, 30(3), 196-215.

Gammoh, B., Mallin, M., Pullins, E. B., \& Johnson, C. (2018). The role of salesperson brand selling confidence in enhancing important sales management outcomes: A social identity approach. Journal of Business \& Industrial Marketing.

Gentile-Lüdecke, S. (2014). Selling to Chinese Firms: A Seller's Perspective. Empirical Evidence from the German Automotive Industry. Multinational Enterprises, Markets and Institutional Diversity, 9, 477-503.

Kantur, D. (2016). Strategic Entrepreneurship: Mediating the Entrepreneurial Orientation-Performance Link. Management Decision, 54(1), 24-43.

Kattenbach, R., \& Fietze, S. (2018). Entrepreneurial Orientation and The Jobs Demand-Resource Model. Personnel Review, 47(3), 745-764.

Kropp, F., Lindsay, N., \& Shoham, A. (2008). Entrepreneurial Orientation and International Entrepreneurial Business Venture Startup. International Journal of Entrepreneurial Behavior \& Research, 14(2), 102-117.

Lee, J., \& Roh, J. J. (2012). Review The Company and The Relationship of The Company's Performance. Benchmarking: An International Journal, 19(4/5), 649-664.

Liu, L., Qu, W., \& Haman, J. (2018). Market Product Competition, Stateownership, Corporate Governance and Firm Performance. Asian Accounting Review, 26(1), 62-83. 
Mani, Y., \& Lakhal, L. (2015). Exploring Family Effects on Company Performance: The Impact of Internal Social Capital Dimensions on Family Company Performance. International Journal of Entrepreneurial Behavior \& Research, 21(6), 898-917.

Mullens, D. (2018). Entrepreneurial Orientation and Sustainability Initiatives in Family Firms. Journal of Global Responsibility, 9(2), 160-178.

Ngoma, M., Ernest, A., Nangoli, S., \& Christopher, K. (2017). Internationalisation of SMEs: Does Entrepreneurial Orientation Matter? World Journal of Entrepreneurship, Management and Sustainable, 13(2), 96-113.

Oltra, M. J., Flor, M. L., \& Alfaro, J. (2018). Open Innovation and Firm Performance: The Role of Organization Mechanisms. Business Process Management Journal, 24(3), 814-836.

Pratono, A. H., \& Mahmood, R. (2015). Mediating effect of marketing capability and reward philosophy in the relationship between entrepreneurial orientation and firm performance. Journal of Global Entrepreneurship Research, 5(5), 1-12.

Pratono, A.H. (2016). Strategic orientation and information technological turbulence: Contingency perspective in SMEs", Business Process Management Journal, 22(2), 368-382, https://doi.org/10.1108/BPMJ05-2015-0066

Pratono, A.H. \& Tjahjono, G. (2017) "How does materialistic attitude influence the impact of corporate brand on the customers' intention to donate to corporates' charity?, Humanomics, 33(4), 484-498, https://doi.org/10.1108/H-07-2016-0052

Pratono, A.H., Suyanto, Marciano, D., \& Zurbrügg, C. (2017). Social return on investment for community-based enterprise in Surabaya City, The Hong Kong Journal of Social Work 51 (01n02), 93-114

Pratono, A.H., (2018) Does firm performance increase with risk-taking behavior under information technological turbulence?: Empirical evidence from Indonesian SMEs", The Journal of Risk Finance, 19(4), 361-378, https://doi.org/10.1108/JRF-10-2017-0170

Pratono, A.H. (2018). From social network to firm performance: The mediating effect of trust, selling capability and pricing capability, Management Research Review 41 (6), 680-700

Pratono, A.H. (2018). Linking religiosity to citizenship behaviour under materialism attitude: Empirical evidence from Indonesia", International 
Journal of Ethics and Systems, https://doi.org/10.1108/IJOES-07-20180104

Pratono A.H. (2018). Network structure and open innovation: the role of trust in product development International Journal of Business Innovation and Research, 15 (1), 44-61.

Pratono, A.H., Ratih, R.V.S., Arshad, D. (2018). Does Entrepreneurial Autonomy Foster SME Growth Under Technological Turbulence? The Empirical Evidence from Indonesia, Journal of Technology in Behavioral Science, 3(3), 170-178.

Rezaei, J., \& Ortt, R. (2018). Entrepreneurial Orientation and Firm Performance: The Mediating Role of Functional Performances. Management Research Review, 41(7), 878-900. 